\title{
Epidemiology of Atypical Hemolytic Uremic Syndrome: A Systematic Literature Review
}

This article was published in the following Dove Press journal: Clinical Epidemiology

\author{
Kevin Yan ${ }^{1,2}$ \\ Kamal Desai ${ }^{\prime}$ \\ Lakshmi Gullapalli (D) \\ Eric Druyts \\ Chakrapani Balijepalli iD ${ }^{\prime}$ \\ 'Pharmalytics Group, Vancouver, British \\ Columbia, Canada; ${ }^{2}$ Faculty of Medicine, \\ University of British Columbia, \\ Vancouver, British Columbia, Canada
}

Correspondence: Chakrapani Balijepalli 637 East I5th Ave, Vancouver, British Columbia V5T 3K5, Canada

$\mathrm{Tel}+$ I 604-398-4025

Email chak.balijepalli@pharmalyticsgroup. com

\begin{abstract}
Atypical hemolytic uremic syndrome (aHUS) is a rare but severe disorder that frequently has a genetic component and results from the overactivation of the alternative complement pathway. As research moves toward improved diagnosis and therapy of aHUS, it will be important to better understand its epidemiology. Our objective was to conduct a systematic literature review to assess the incidence and prevalence estimates of aHUS globally. A comprehensive literature search was conducted in Embase and MEDLINE. Additionally, practice guidelines, databases of national/international organizations, and regulatory agencies were searched. From 2960 publications identified via MEDLINE and Embase, 105 publications were eligible for full-text screening, and a total of eight full-text articles met eligibility criteria for inclusion. Regional epidemiologic estimates were obtained for Europe and Oceania. Country-specific data were available for France, Norway, Australia, and Italy. Four of the identified studies reported on the prevalence of aHUS, prevalence in the age group of 20 years or younger was ranging from 2.2 to 9.4 per million population, while the only study that reported prevalence in all ages showed a prevalence of 4.9 per million population. Six studies reported on the incidence of aHUS, annual incidence in the age group of 20 years or younger was ranging from 0.26 to 0.75 per million population, and for all ages, annual incidence was ranging from 0.23 to 1.9 per million population. To our knowledge, this is the first systematic review conducted to provide a comprehensive overview of global incidence and prevalence estimates of aHUS. In general, incidence estimates were similar across all the studies; however, prevalence data were found to be more variable. Study limitations were related to inconsistencies in the definitions of aHUS between studies and also a dearth of epidemiological studies assessing incidence and prevalence of aHUS outside of Europe.
\end{abstract}

Keywords: incidence, prevalence, aHUS, rare, orphan, kidney

\section{Introduction}

Atypical hemolytic uremic syndrome (aHUS) is a severe disorder that frequently has a genetic component and results from the overactivation of the alternative complement pathway. ${ }^{1,2}$ The disease primarily affects kidney function and is characterized by hemolytic anemia, thrombocytopenia, and renal impairment. ${ }^{3}$ Extrarenal complications involving the central nervous (drowsiness, seizures, encephalopathy, cortical blindness), cardiovascular (cardiomyopathy, myocardial infarction, heart failure), pulmonary (pulmonary hemorrhage), gastrointestinal (pancreatitis, intestinal bleeding), and skeletal system (rhabdomyolysis) are common and can occur in up to $20 \%$ of cases. ${ }^{4,5}$ An atypical classification of hemolytic uremic syndrome is usually defined with origins unrelated to cobalamin deficiency, streptococci, shiga toxin-producing bacteria, or 
other infections (influenza A, H1N1, HIV).$^{6-9}$ Moreover, HUS (hemolytic uremic syndrome) with comorbidities (eg. autoimmune diseases, haemopoietic stem cell transplantation, malignancy, pre-existing nephropathy) can exclude an aHUS diagnosis. ${ }^{8}$ Most cases of aHUS are associated with mutated complement factor genes which occur particularly in children. ${ }^{6,9-13}$ In children, aHUS affects females and males equally; while in adults, it occurs more frequently in females than males. ${ }^{4}$ Subjects with complement factor $\mathrm{H}$ mutations have less favourable prognosis and outcomes compared to individuals with no genetic mutations. ${ }^{14,15}$

Due to the rarity of the disease, global aHUS disease epidemiology is not well known. ${ }^{16}$ When reported, incidence and prevalence estimates are often combined with similar disorders such as shiga toxin-producing e.coli associated hemolytic uremic syndrome (STEC-HUS) or thrombotic thrombocytopenic purpura (TTP), leading to inaccurate estimates of the true number of individuals diagnosed with aHUS. ${ }^{17-19}$ Although population-based estimates exist for some countries, there are gaps in global aHUS incidence and prevalence. A detailed overview of aHUS epidemiology is needed to help facilitate further understanding of its disease burden. Moreover, as improved diagnosis and therapies of aHUS are developed, agencies that review new technologies and health systems that deliver them will require better estimates of aHUS incidence and prevalence.

To our knowledge, no systematic reviews or meta-analysis have been performed to determine the global epidemiology of aHUS. To address this gap in the literature, we conducted a review of international aHUS incidence and prevalence to provide a comprehensive overview of the current epidemiological landscape.

\section{Materials and Methods}

A comprehensive literature search was conducted in Embase and MEDLINE without date limitations on October 20, 2019 (detailed search strategies in Supplementary Materials S1 and $\underline{\mathrm{S}}$ ). Additionally, we reviewed practice guidelines, national/international organizations (eg World Health Organization, National Organization for Rare Disorders, European Network for Health Technology Assessment, aHUS Foundation, National Institute of Diabetes and Digestive and Kidney, U.S. National Library of Medicine), and regulatory agencies (eg, The National Institute for Health and Care Excellence, Canadian Agency for Drugs and Technologies in Health, U.S. Food \& Drugs Administration, European Medicines Agency, Institute for Quality and Efficiency in Health Care, Pharmaceutical Benefits Advisory
Committee, Haute Autorité de Santé, Pharmaceutical Management Agency). We also searched the following conferences from the past two years: International Society for Pharmacoepidemiology (ISPE 2018 and 2019), International Society for Pharmacoeconomics and Outcomes Research (ISPOR 2018 and 2019), European Conference on Rare Diseases \& Orphan Products (ECRD 2018). The PRISMA checklist was used to ensure completeness of all reported items (Supplementary Materials S6). A protocol adhering to Cochrane guidelines for conducting systematic literature reviews was developed and peer-reviewed internally.

Eligibility criteria were based on population definition and study type. The population of interest were individuals diagnosed with atypical hemolytic uremic syndrome. Studies focusing exclusively on pregnancy-associated aHUS (p-aHUS) were excluded. Eligible studies included population-based observational studies assessing the incidence and/or prevalence of aHUS. Studies not published in English were excluded (Supplementary Materials S3).

Diagnosis of aHUS is most commonly defined as the absence of shiga toxin-producing e.coli (STEC) or other infection-related HUS, absence of cobalamin-associatedHUS, and ADAMTS13 activity $>5-10 \%{ }^{8,9,20}$ Due to the potential of including other HUS disorders in epidemiologic estimates, aHUS incidence and prevalence must have been strictly defined separately from all other HUS'. Moreover, studies were excluded if they did not report incidence or prevalence numbers explicitly for aHUS.

\section{Data Screening and Extraction}

All abstracts identified in the literature searches were screened for study eligibility. Abstracts deemed eligible were screened again by viewing the complete study publication to make a final determination as to whether or not they met the inclusion criteria. Data were then extracted from these studies, including study design characteristics (design, geographic location, database source, study duration, aHUS definition) population attributes (age, gender, medical history, laboratory values), outcomes (prevalence and incidence estimates), and study quality assessment (National Institutes of Health Quality Assessment Tool for observational cohort and cross-sectional studies; Supplementary Materials S4). ${ }^{21}$ Study screening and data extraction were performed by two individuals working independently (KY and LG). These individuals compared their completed work to identify any discrepancies and resolve these through consensus, including a third individual if needed. 


\section{Evidence Synthesis}

We initially planned to conduct a meta-analysis of prevalence and incidence. However, given the lack of uncertainty estimates (standard deviation, standard error, confidence intervals) and the heterogeneity in the identified studies, we assessed studies qualitatively.

\section{Results}

The selection process to identify studies that report aHUS incidence and prevalence is summarized in the PRISMA flow diagram (Figure 1). ${ }^{22}$ A total of 2960 publications were identified via MEDLINE and Embase. No further studies were identified from searching practice guidelines, national/international organizations, and regulatory agencies. After abstract screening, 105 publications were eligible for full-text screening. A total of eight full-text articles met all inclusion criteria and were retained for data extraction. Using the National Institutes of Health Quality Assessment Tool, seven studies were identified to be of good quality and one study was assessed to be fair quality. Zimmerhackl 2006 was considered fair quality due to the nature of its case detection: prior to 2001 cases of aHUS were collected voluntarily, thereby potential cases may have been missed (Supplementary Materials S5). ${ }^{23}$

All studies were conducted in Europe, Australia, or New Zealand. Prevalence and incidence estimates were drawn from a combination of population-based registry, hospital, and national surveillance data. Of the eight studies, five studies were retrospective, ${ }^{13,24-27}$ one study was prospective, ${ }^{28}$ one study was cross-sectional, ${ }^{29}$ and one study was initially crosssectional then data were collected prospectively after $2001 .^{23}$ Three studies were conducted in individuals of all ages, ${ }^{13,24,27}$ four studies were conducted in pediatrics $(<18$ years old), ${ }^{23,25,26,28}$ and one was conducted in adults ( $>18$ years old). ${ }^{29}$ Fremeaux-Bacchi et al (2013) included individuals of all ages; however, they reported baseline characteristics by age group ( $<16$ years old, $\geq 16$ years old). Two of the eight studies used diagnostic codes from registries to identify aHUS cases. $^{27,29}$ There was heterogeneity surrounding aHUS
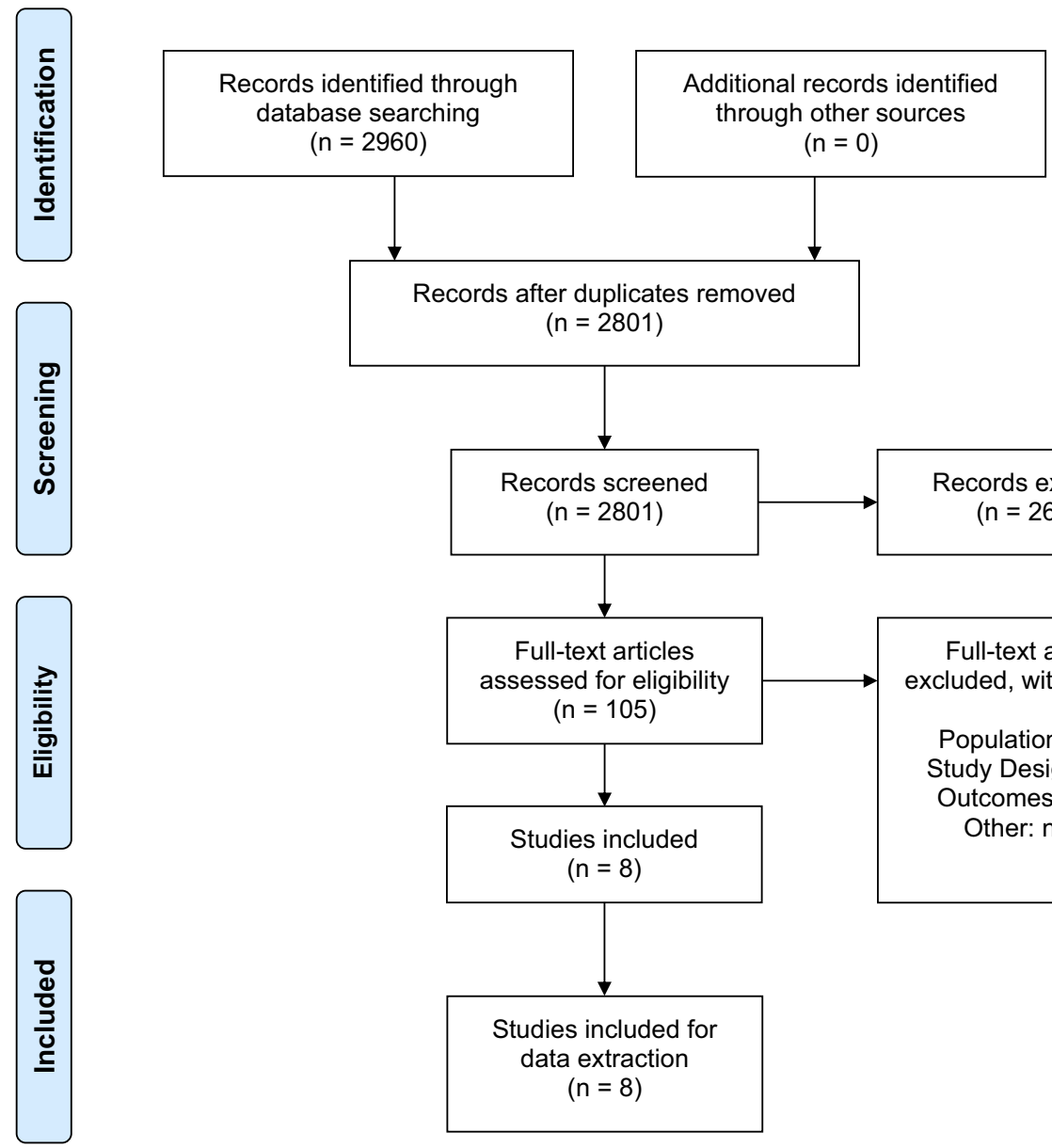

Records after duplicates removed $(n=2801)$

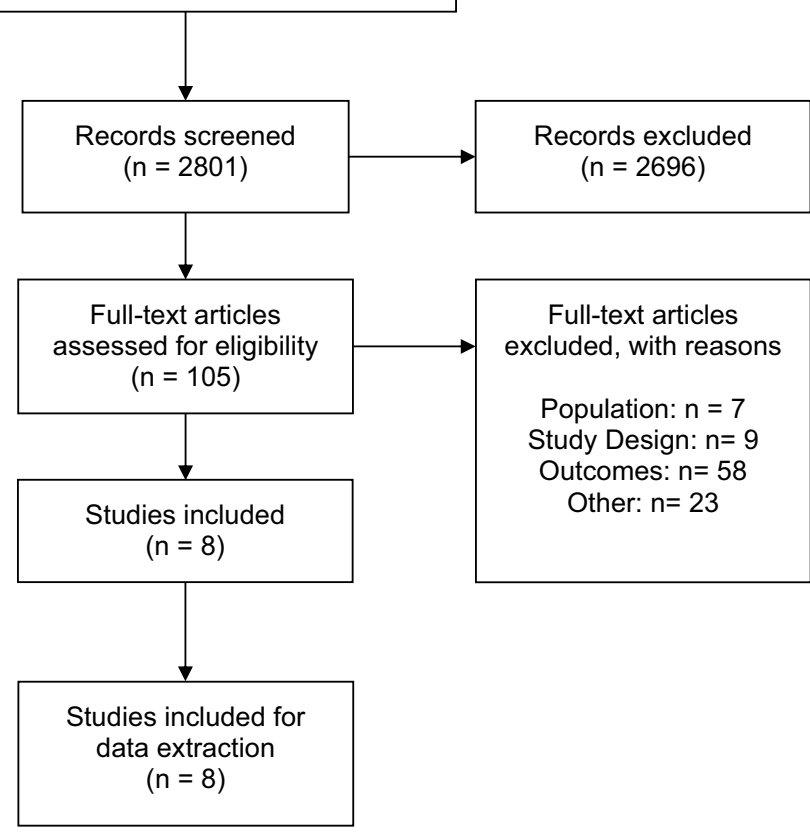

Figure I PRISMA study flow diagram. Adapted from Moher D, Liberati A, Tetzlaff J, Altman DG, The PRISMA Group (2009) Preferred Reporting Items for Systematic Reviews and Meta-Analyses: The PRISMA Statement. PLoS Med 6(7): el000097. Creative Commons license and disclaimer available from: http://creativecommons.org/ licenses/by/4.0/legalcode. ${ }^{22}$ 
definitions across the included studies. All non-registry studies unanimously defined aHUS cases to be tested STEC negative. Three studies further required cases to have an absence of diarrhea. $^{23,25,26}$ Bayer et al (2019) and Fremeaux-Bacchi et al (2013) were more stringent in their case definitions whereby cases were excluded if they also had particular comorbidities such as an autoimmune disease or organ transplantation (Table 1). ${ }^{13,24}$ Baseline characteristics are summarized in Table 2. Studies reporting pediatric baseline characteristics showed the mean age of diagnosis was under 2 years old and were approximately evenly split in gender. ${ }^{13,23,26,28}$ The mean age of diagnosis in adults was between 31 and 37 years old and unlike the pediatric population, the majority of individuals affected were females. ${ }^{13,24,29}$ The majority of patients required dialysis at the acute phase of aHUS and almost all were anemic. Five studies reported some form of baseline characteristics. However, overall reporting was sparse with only three studies extensively providing detailed baseline characteristics.

Prevalence and incidence estimates were reported in four ${ }^{23,25,27,29}$ and $\operatorname{six}^{13,24-28}$ studies, respectively (Figures 2 and 3). Incidence was measured per million annually in all except one study, Jenssen 2014 measured incidence per $100,000 .^{26}$ Prevalence was measured per million individuals across all included studies. The reported observation period for studies ranged between 4 and 29 years, with six studies reporting periods of 7 years or longer. Three studies reported prevalence at a continental or regional level, one of which also reported incidence. ${ }^{23,27,29}$ Each of the five remaining studies reported country-specific incidence, including two for France, one for Norway, one for Australia, and one for Italy, which also reported prevalence. ${ }^{13,24-26,28}$

\section{Incidence}

In Europe reported incidence ranged between 0.23 and 1.9 per million annually in the population (Table 3). ${ }^{13,24}$ In Australia the only identified study was conducted in pediatrics, 14 cases were reported with a calculated incidence of 0.44 per million annually. ${ }^{28}$ Studies reporting incidence for individuals under 20 years of age ranged between 0.26 and 0.75 per million annually. ${ }^{25,27}$ Meanwhile, in adult studies, incidence ranged between 0.42 and 1.9 per million annually. ${ }^{24,27}$ Two studies were conducted in France and showed an increase in incidence between 2000 and 2016. ${ }^{13,24}$ The largest reference population was in Europe, with more than 745 million people (745 243760 ) and incidence of aHUS was 0.39 per million total population annually. ${ }^{27}$

\section{Prevalence}

In individuals under 20 years of age, prevalence ranged between 2.21 and 9.4 per million people (Table 3). ${ }^{25,27}$ Jenssen 2014 further reported prevalence by age group and found the highest prevalence to be in children between 0 and 4 years of age ( 3 per million children population). Between ages 5-9 and 10-15, prevalence declined to 0.3 to 0 per million children population. ${ }^{26}$ Prevalence in adults was higher in Europe compared to Australia/New Zealand (5.75 to 2.4 per million people, respectively). ${ }^{27,29}$ The largest reference population was in Europe, with more than 16 million people $(16,427365)$ and prevalence of aHUS was 4.96 per million total population. ${ }^{27}$

\section{Discussion}

This systematic review provided a comprehensive overview of currently available incidence and prevalence estimates globally of aHUS. Incidence was found to range between 0.23 and 1.9 per million population annually, depending on region and age group. Prevalence figures ranged from around two to ten per million population, also depending on region and age. Studies assessing incidence of aHUS in the pediatric age group were conducted predominantly in Europe and Australia; results were comparable between studies for this age group. Prevalence data for pediatrics were primarily from Europe, with the highest estimate observed in one Italian study. Studies reporting incidence in adults were also mainly conducted in Europe, with one study in France having a noticeably higher number of observed new aHUS diagnoses per year. Prevalence data for adults were available from studies predominantly conducted across Europe and Australia, with similar estimates found between studies.

To our knowledge, no systematic reviews have been conducted to survey the global epidemiologic landscape of aHUS. Although a protocol was previously published to determine incidence and prevalence of aHUS in Iran, no data appears to have been reported yet from this study. ${ }^{30}$ We found that the majority of studies in the literature examined broadly defined conditions such as HUS, TTP, or STEC-HUS. ${ }^{31-33}$ One study of note that we did not include investigated non-enteropathic hemolytic uremic syndrome, a condition closely related to aHUS, in the United States. Although results from this study have been used to inform aHUS incidence in the United States, we did not include this study in our systematic literature review because we focused exclusively on studies assessing aHUS only.,34 
Table I Design Characteristics of Studies Examining Incidence and Prevalence of Atypical Hemolytic Uremic Syndrome

\begin{tabular}{|c|c|c|c|c|c|c|c|c|}
\hline $\begin{array}{l}\text { Study } \\
\text { Name }\end{array}$ & $\begin{array}{l}\text { Study } \\
\text { Type }\end{array}$ & Country & $\begin{array}{l}\text { Source of } \\
\text { Data }\end{array}$ & $\begin{array}{l}\text { Study } \\
\text { Design }\end{array}$ & $\begin{array}{l}\text { Study } \\
\text { Period }\end{array}$ & $\begin{array}{l}\text { Study-Reported } \\
\text { aHUS Case } \\
\text { Definition }\end{array}$ & Case Selection & Age \\
\hline Bayer $2019^{24}$ & $\begin{array}{l}\text { Full- } \\
\text { text } \\
\text { article }\end{array}$ & France & $\begin{array}{l}\text { Four- } \\
\text { hospital } \\
\text { institution in } \\
\text { France }\end{array}$ & Retrospective & $2009-2016$ & $\begin{array}{l}\text { TMA/kidney failure } \\
\text { with no evidence of } \\
\text { drug use known to } \\
\text { be associated with } \\
\text { TMAs, } \\
\text { transplantations, no } \\
\text { STEC infection, } \\
\text { cancers, } \\
\text { autoimmune disease, } \\
\text { and severe/malignant } \\
\text { hypertension } \\
\text { (hypertensive } \\
\text { retinopathy and } \\
\text { diastolic arterial } \\
\text { pressure over } 120 \\
\text { mmHg). }\end{array}$ & $\begin{array}{l}\text { Patients hospitalized } \\
\text { in our four-hospital } \\
\text { institution (Centre } \\
\text { Hospitalier } \\
\text { Universitaire [CHU] } \\
\text { Tours, France) who } \\
\text { were suspected of } \\
\text { having a first } \\
\text { episode of TMA } \\
\text { were included. CHU } \\
\text { Tours includes four } \\
\text { hospitals of the } \\
\text { Centre area of } \\
\text { France. }\end{array}$ & $\begin{array}{l}\text { All } \\
\text { ages }\end{array}$ \\
\hline $\begin{array}{l}\text { Ardissino } \\
2016^{25}\end{array}$ & $\begin{array}{l}\text { Full- } \\
\text { text } \\
\text { article }\end{array}$ & Italy & $\begin{array}{l}\text { HUS } \\
\text { network } \\
\text { containing } \\
56 \text { pediatric } \\
\text { units in } \\
\text { Lombardy }\end{array}$ & Retrospective & $2003-2012$ & $\begin{array}{l}\text { HUS with no } \\
\text { evidence of diarrhea } \\
\text { or STEC infection }\end{array}$ & $\begin{array}{l}\text { The study includes } \\
\text { all of the incident } \\
\text { cases occurring in } \\
\text { patient's resident } \\
\text { within the } \\
\text { administrative } \\
\text { boundaries of the } \\
\text { Lombardy Region of } \\
\text { Italy who } \\
\text { experienced } \\
\text { a documented first } \\
\text { episode of HUS } \\
\text { before the age of } 18 \\
\text { years }\end{array}$ & $\begin{array}{l}\leq 18 \\
\text { years } \\
\text { old }\end{array}$ \\
\hline $\begin{array}{l}\text { Durkan } \\
2016^{28}\end{array}$ & $\begin{array}{l}\text { Full- } \\
\text { text } \\
\text { article }\end{array}$ & Australia & $\begin{array}{l}\text { Australian } \\
\text { Pediatric } \\
\text { Surveillance } \\
\text { Unit } \\
\text { (National } \\
\text { Surveillance) }\end{array}$ & Prospective & $|994-200|$ & $\begin{array}{l}\text { HUS with no } \\
\text { evidence of STEC } \\
\text { infection or } \\
\text { Streptococcus } \\
\text { pneumoniae infection }\end{array}$ & $\begin{array}{l}\text { Active surveillance } \\
\text { programme of all } \\
\text { cases of HUS in } \\
\text { children aged less } \\
\text { than } 15 \text { years }\end{array}$ & $\begin{array}{l}\leq 15 \\
\text { years } \\
\text { old }\end{array}$ \\
\hline $\begin{array}{l}\text { Jenssen } \\
2014^{26}\end{array}$ & $\begin{array}{l}\text { Full- } \\
\text { text } \\
\text { article }\end{array}$ & Norway & $\begin{array}{l}24 \text { pediatric } \\
\text { hospitals }\end{array}$ & Retrospective & 1999-2008 & $\begin{array}{l}\text { HUS with no } \\
\text { evidence of diarrhea } \\
\text { or STEC infection }\end{array}$ & $\begin{array}{l}\text { Patients }<16 \text { years } \\
\text { and all hospitals with } \\
\text { capacity, } \\
\text { competence, or } \\
\text { supportive care of } \\
\text { HUS and/or AKI } \\
\text { patients were } \\
\text { included. }\end{array}$ & $\begin{array}{l}<16 \\
\text { years } \\
\text { old }\end{array}$ \\
\hline
\end{tabular}

(Continued) 
Table I (Continued).

\begin{tabular}{|c|c|c|c|c|c|c|c|c|}
\hline $\begin{array}{l}\text { Study } \\
\text { Name }\end{array}$ & $\begin{array}{l}\text { Study } \\
\text { Type }\end{array}$ & Country & $\begin{array}{l}\text { Source of } \\
\text { Data }\end{array}$ & $\begin{array}{l}\text { Study } \\
\text { Design }\end{array}$ & $\begin{array}{l}\text { Study } \\
\text { Period }\end{array}$ & $\begin{array}{l}\text { Study-Reported } \\
\text { aHUS Case } \\
\text { Definition }\end{array}$ & Case Selection & Age \\
\hline $\begin{array}{l}\text { Mallett } \\
2014^{29}\end{array}$ & $\begin{array}{l}\text { Full- } \\
\text { text } \\
\text { article }\end{array}$ & Australia/NZ & $\begin{array}{l}\text { CKD.QLD } \\
\text { Registry }\end{array}$ & $\begin{array}{l}\text { Cross- } \\
\text { sectional }\end{array}$ & 2013 & $\begin{array}{l}\text { aHUS defined in the } \\
\text { registry }\end{array}$ & $\begin{array}{l}\text { All patients with } \\
\text { clinically diagnosed } \\
\text { CKD, were } 18 \text { years } \\
\text { or older and had } \\
\text { attended public } \\
\text { nephrology } \\
\text { practices in } \\
\text { Queensland }\end{array}$ & $\begin{array}{l}>18 \\
\text { years } \\
\text { old }\end{array}$ \\
\hline Wuhl $2014^{27}$ & $\begin{array}{l}\text { Full- } \\
\text { text } \\
\text { article }\end{array}$ & $\begin{array}{l}\text { Austria, } \\
\text { Denmark, } \\
\text { Spain, Finland, } \\
\text { France, } \\
\text { Greece, } \\
\text { Netherlands, } \\
\text { Norway, } \\
\text { Romania, } \\
\text { Sweden, } \\
\text { Scotland }\end{array}$ & $\begin{array}{l}\text { ERA-EDTA } \\
\text { Registry }\end{array}$ & Retrospective & $2007-2011$ & $\begin{array}{l}\text { aHUS PRD } \\
\text { diagnostic code }\end{array}$ & $\begin{array}{l}\text { Patients of all ages } \\
\text { with aHUS were } \\
\text { extracted from the } \\
\text { ERA-EDTA Registry }\end{array}$ & $\begin{array}{l}\text { All } \\
\text { ages }\end{array}$ \\
\hline $\begin{array}{l}\text { Fremeaux- } \\
\text { Bacchi } 2013^{13}\end{array}$ & $\begin{array}{l}\text { Full- } \\
\text { text } \\
\text { article }\end{array}$ & France & $\begin{array}{l}\text { French } \\
\text { National } \\
\text { Study }\end{array}$ & Retrospective & $2000-2008$ & $\begin{array}{l}\text { No HUS secondary } \\
\text { to drugs, } \\
\text { autoimmune } \\
\text { diseases, due to the } \\
\text { number of infections } \\
\text { (STEC, Streptococcus } \\
\text { pneumoniae, or HIV), } \\
\text { bone marrow or } \\
\text { solid organ } \\
\text { transplantation, and } \\
\text { cobalamin deficiency }\end{array}$ & $\begin{array}{l}\text { Included patients } \\
\text { with atypical HUS } \\
\text { excluding all cases of } \\
\text { secondary aHUS } \\
\text { except pregnancy. } \\
\text { Excluded patients } \\
\text { with HUS secondary } \\
\text { to drugs, } \\
\text { autoimmune } \\
\text { diseases, infections } \\
\text { (caused by STEC, } \\
\text { Strep. pneumoniae, } \\
\text { or HIV), bone } \\
\text { marrow/organ } \\
\text { transplant, and } \\
\text { cobalamin deficiency }\end{array}$ & $\begin{array}{l}\text { All } \\
\text { ages }\end{array}$ \\
\hline $\begin{array}{l}\text { Zimmerhackl } \\
2006^{23}\end{array}$ & $\begin{array}{l}\text { Full- } \\
\text { text } \\
\text { article }\end{array}$ & $\begin{array}{l}\text { Austria, } \\
\text { Germany, } \\
\text { Czechia, } \\
\text { Hungary, } \\
\text { Switzerland, } \\
\text { UK, Italy, } \\
\text { Turkey, } \\
\text { Netherlands, } \\
\text { Israel, } \\
\text { Sweden, } \\
\text { France }\end{array}$ & $\begin{array}{l}\text { European } \\
\text { registry }\end{array}$ & $\begin{array}{l}\text { Cross- } \\
\text { sectional } \\
\text { (Prospective } \\
\text { after 200I) }\end{array}$ & $1974-2005$ & $\begin{array}{l}\text { HUS with no } \\
\text { evidence of diarrhea } \\
\text { or STEC infection }\end{array}$ & $\begin{array}{l}\text { Patients < } 18 \text { years } \\
\text { old with aHUS were } \\
\text { extracted from the } \\
\text { European Registry }\end{array}$ & $\begin{array}{l}<18 \\
\text { years } \\
\text { old }\end{array}$ \\
\hline
\end{tabular}

Abbreviations: UK, United Kingdom; NZ, New Zealand; STEC, Shiga toxin-producing E. coli; HUS, hemolytic uremic syndrome; aHUS, atypical hemolytic uremic syndrome; TMA, thrombotic microangiopathy. 


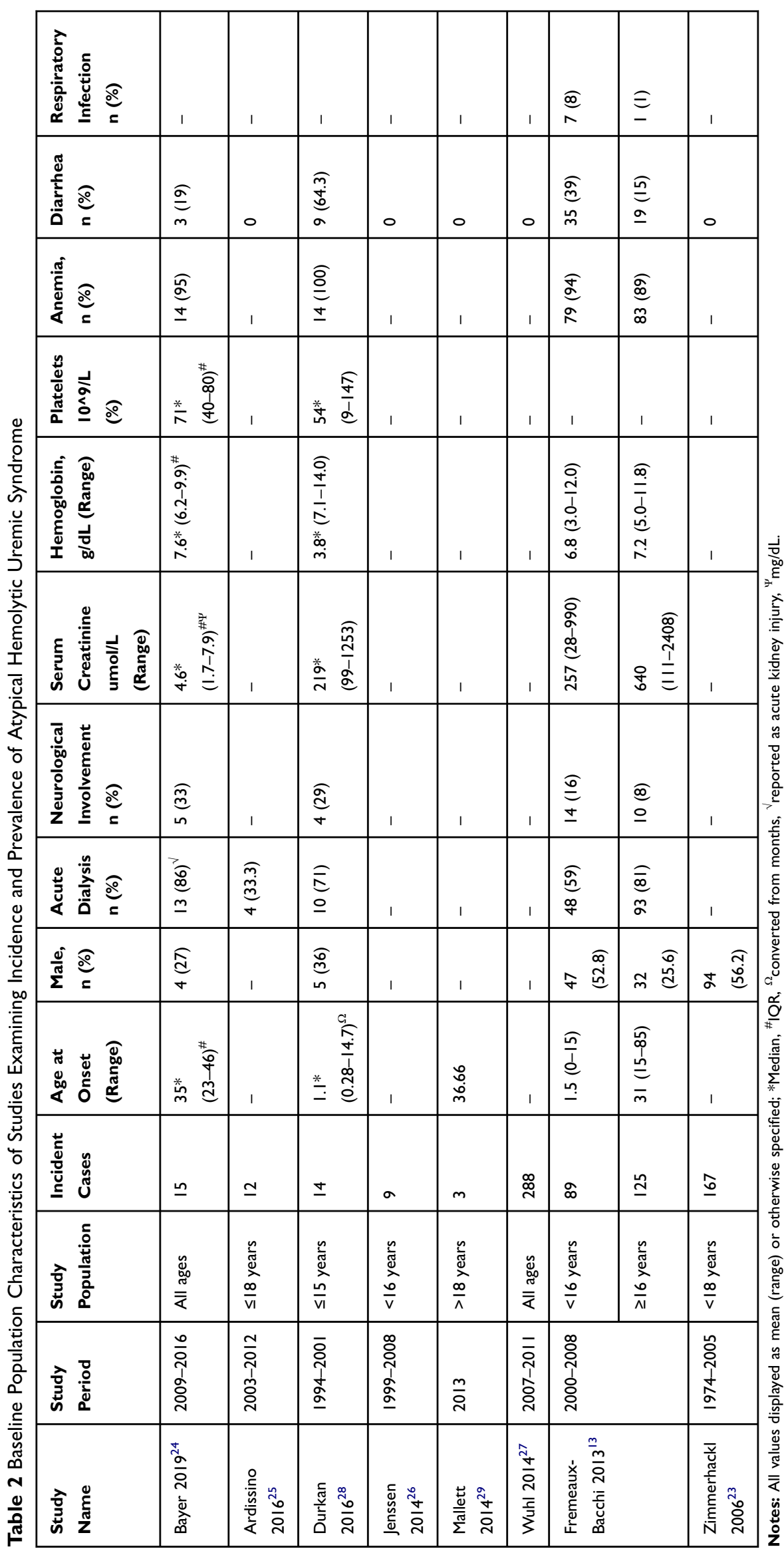




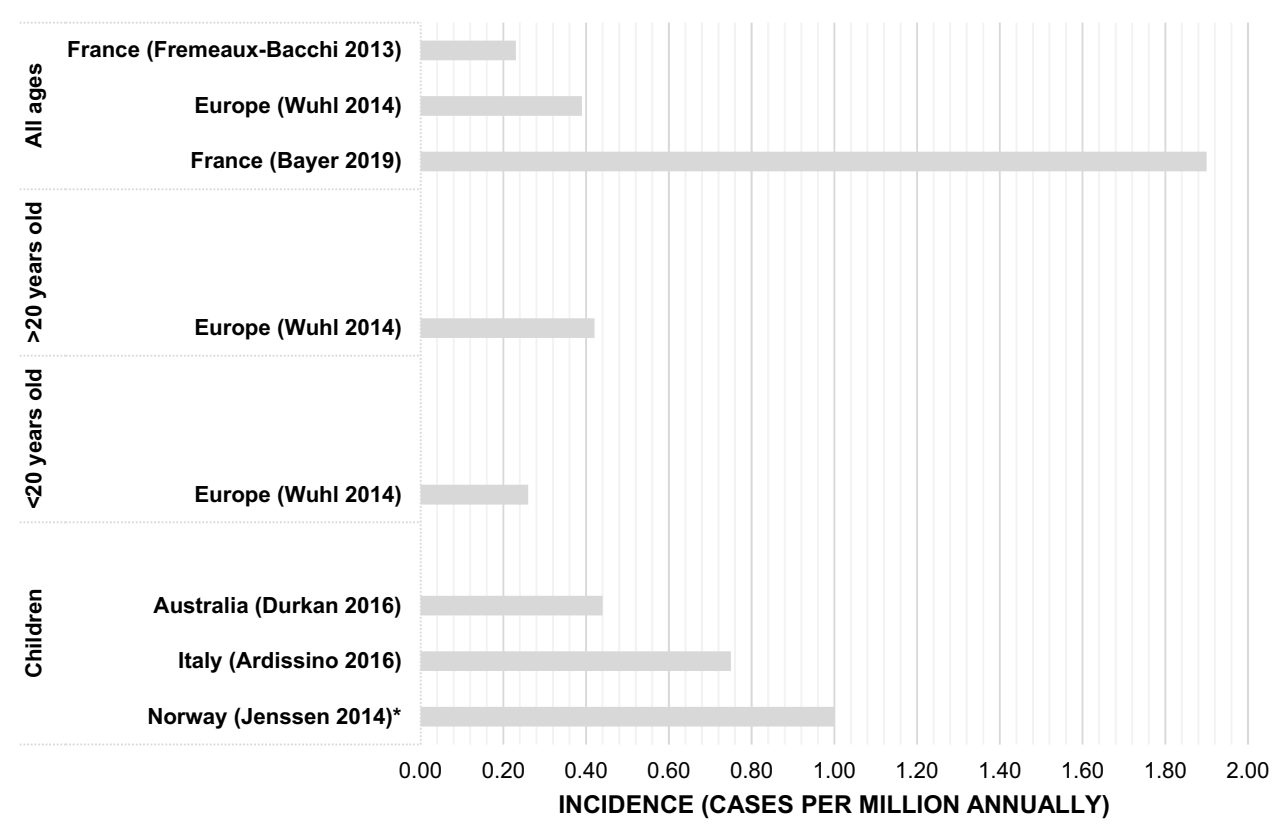

Figure 2 Studies reporting countries with reported incidence estimates by age group. Note: *Jenssen 2014 reported incidence <1 per million annually (Range: $0-3$ ).

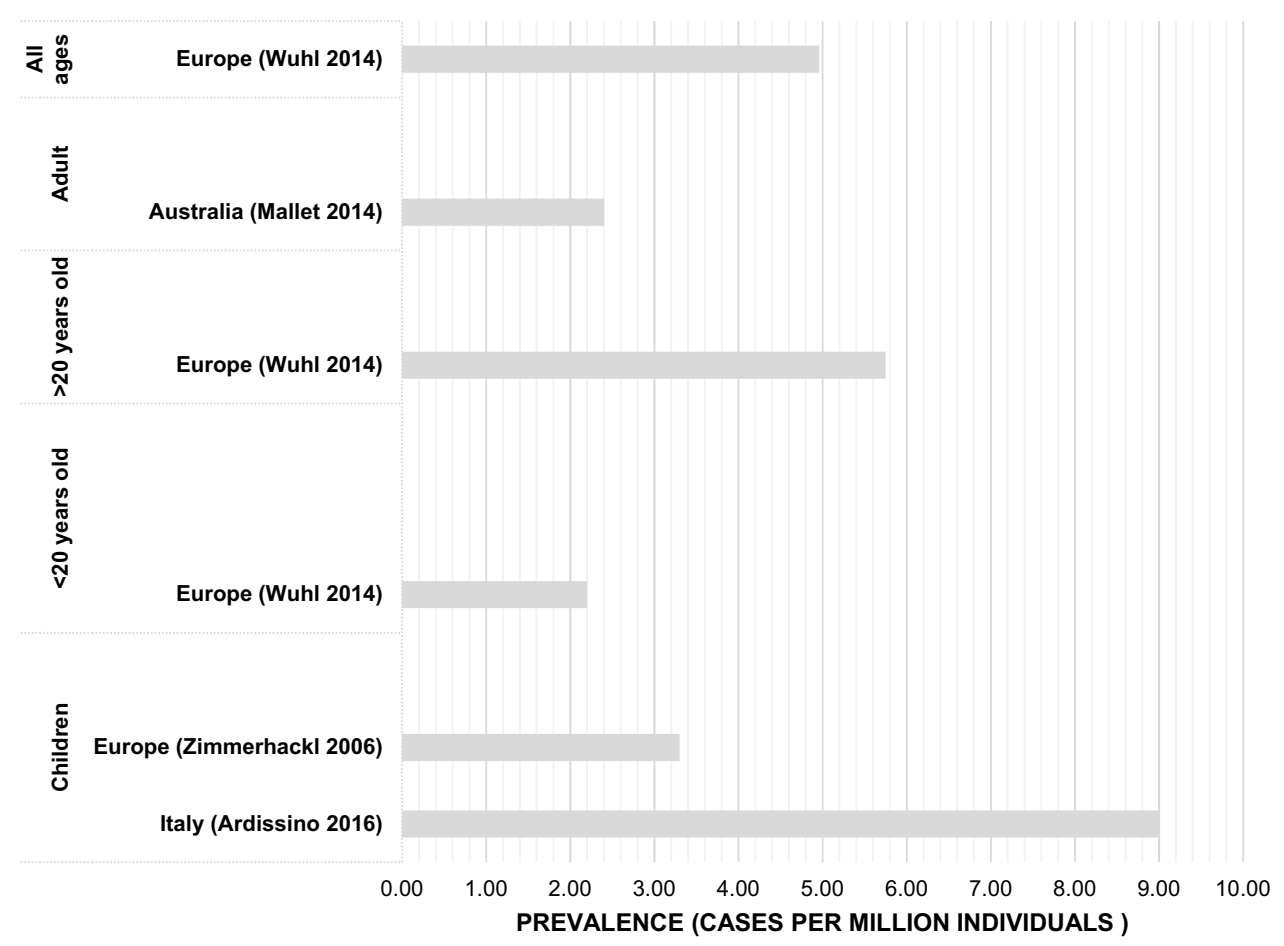

Figure 3 Studies reporting countries with reported prevalence estimates by age group.

We found the case definitions for aHUS to be heterogenous across the included studies. This could be due to the heterogeneity of patients with aHUS and ambiguity surrounding clinical presentation and difficulties with diagnosis of the condition. ${ }^{10}$ A small proportion of cases included in the study conducted by Fremeaux-Bacchi et al
(2013) were pregnancy-induced aHUS; consequently, the true incidence of non-pregnancy associated aHUS may be moderately lower in this study. ${ }^{13}$ The two studies (Fremeaux-Bacchi et al, 2013 and Bayer, 2019) conducted in France showed an increasing incidence of aHUS in more recent years. ${ }^{13,24}$ This could possibly be due to an 
Table 3 Incidence and Prevalence of Atypical Hemolytic Uremic Syndrome

\begin{tabular}{|c|c|c|c|c|c|c|}
\hline Study & Country & $\begin{array}{l}\text { Study } \\
\text { Period }\end{array}$ & Age & $\begin{array}{l}\text { Total } \\
\text { aHUS } \\
\text { Cases }\end{array}$ & $\begin{array}{l}\text { Incidence per } \\
\text { Million } \\
\text { Annually } \\
\text { (Range) }\end{array}$ & $\begin{array}{l}\text { Prevalence } \\
\text { per Million }\end{array}$ \\
\hline Bayer 2019*24 & France & $2009-2016$ & All ages & 15 & 1.9 & - \\
\hline $\begin{array}{l}\text { Ardissino } \\
2016^{25}\end{array}$ & Italy & $2003-2012$ & $\leq 18$ years old & 12 & 0.75 & 9.4 \\
\hline Durkan $2016^{28}$ & Australia & $|994-200|$ & $\leq 15$ years old & 14 & 0.44 & - \\
\hline Jenssen $2014^{26}$ & Norway & 1999-2008 & $<16$ years old & 9 & $<1(0-3)$ & - \\
\hline Mallett $2014^{29}$ & Australia/New Zealand & 2013 & $>18$ years old & 3 & - & 2.4 \\
\hline \multirow[t]{3}{*}{ Wuhl $2014^{27}$} & \multirow{3}{*}{$\begin{array}{l}\text { Austria, Denmark, Spain, Finland, France, } \\
\text { Greece, Netherlands, Norway, Romania, } \\
\text { Sweden, Scotland }\end{array}$} & $2007-2011$ & All ages & 815 & 0.39 & 4.96 \\
\hline & & $2007-2011$ & $<20$ years old & 81 & 0.26 & 2.21 \\
\hline & & $2007-2011$ & $>20$ years old & 734 & 0.42 & 5.75 \\
\hline $\begin{array}{l}\text { Fremeaux- } \\
\text { Bacchi } 2013^{13}\end{array}$ & France & $2000-2008$ & All ages & 214 & 0.23 & - \\
\hline $\begin{array}{l}\text { Zimmerhackl } \\
2006^{23}\end{array}$ & $\begin{array}{l}\text { Austria, Germany, Czechia, Hungary, } \\
\text { Switzerland, United Kingdom, Italy, Turkey, } \\
\text { Netherlands, Israel, Sweden, France }\end{array}$ & $1974-2005$ & $<18$ years old & 167 & - & 3.3 \\
\hline
\end{tabular}

Note: *One pediatric case in the study.

improved understanding of the clinical presentation and pathophysiology of the disease, leading to more identified cases. ${ }^{35}$ Prevalence of pediatric aHUS was found to be higher in an Italian study. ${ }^{25}$ This may be due to the study specifying the inclusion of individuals diagnosed with pneumonia-associated HUS or cobalamin-associated HUS in their aHUS cases. Pneumonia-associated HUS is often seen in pediatrics leading to a higher reported incidence compared to the other studies. ${ }^{36}$ Jenssen 2014 included two cases of pneumonia-associated HUS and one case of campylobacter-related HUS, thereby true aHUS incidence may be lower than reported. Wuhl (2014) mapped Orphanet rare disease to the ERA-EDTA PRD codes. The study used ERA-EDTA registry data to report incidence and prevalence of aHUS in end-stage renal disease/ renal replacement therapy (ESRD/RRT) patients. However, the registry was unable to differentiate between aHUS and other HUS conditions and patients who did not reach ESRD/RRT were not included. Moreover, few pediatric patients progress to ESRD/RRT for STEC-HUS, any studies that report a higher proportion of patients reaching ESRD/RRT $<20$ years old suggest that most of these cases are primary aHUS. Due to these limitations, incidence and prevalence of aHUS is most likely underestimated.
This study has some strengths and limitations. This study was not restricted to any geographical location, population, or age group. Moreover, the majority of studies included in our systematic review were of good quality. Case definitions were available to allow for comparability across studies. This study only included validated aHUS cases which provided a more consistent estimate of incidence and prevalence. Nonetheless, across all our included studies, variations in reference population sizes, aHUS case definitions, and study design can potentially impact the number of identified cases. On the other hand, the lack of studies reporting uncertainty estimates and the heterogeneity across study populations did not permit further synthesis of data with a meta-analysis to provide pooled estimates. Surprisingly, population estimates were lacking for other large countries such as the United States or Canada. As a result of sparse reporting of aHUS epidemiology in the literature, we were limited to capturing data from two continents.

\section{Conclusion}

To our knowledge, this is the first systematic review conducted to provide a comprehensive overview of currently available global incidence and prevalence estimates of 
aHUS. In general, incidence estimates were similar across all the studies; however, prevalence data were found to be more variable. Noticeable evidence gaps include inconsistent case definitions for aHUS and a dearth of epidemiological estimates of prevalence and incidence for aHUS outside of Europe.

\section{Disclosure}

The authors declare that there are no conflicts of interest regarding the publication of this paper.

\section{References}

1. Raina R, Krishnappa V, Blaha T, et al. Atypical hemolytic-uremic syndrome: an update on pathophysiology, diagnosis, and treatment. Ther Apher Dial. 2019;23(1):4-21. doi:10.1111/tap.2019.23.issue-1

2. Yoshida Y, Kato H, Ikeda Y, Nangaku M. Pathogenesis of atypical hemolytic uremic syndrome. $J$ Atheroscler Thromb. 2019;26 (2):99-110. doi:10.5551/jat.RV17026

3. Noris M, Remuzzi G. Hemolytic uremic syndrome. J Am Soc Nephrol. 2005;16(4):1035. doi:10.1681/ASN.2004100861

4. Loirat C, Frémeaux-Bacchi V. Atypical hemolytic uremic syndrome. Orphanet J Rare Dis. 2011;6:60. doi:10.1186/1750-1172-6-60

5. Zhang K, Lu Y, Harley KT, Tran M-H. Atypical hemolytic uremic syndrome: a brief review. Hematol Rep. 2017;9(2):7053. doi:10.4081/ hr.2017.7053

6. Noris M, Remuzzi G. Atypical hemolytic-uremic syndrome. $N$ Engl $J$ Med. 2009;361(17):1676-1687. doi:10.1056/NEJMra0902814

7. Sridharan M, Go RS, Willrich MAV. Atypical hemolytic uremic syndrome: review of clinical presentation, diagnosis and management. J Immunol Methods. 2018;461:15-22. doi:10.1016/j.jim.2018.07.006

8. Fakhouri F, Zuber J, Frémeaux-Bacchi V, Loirat C. Haemolytic uraemic syndrome. Lancet. 2017;390(10095):681-696. doi:10.1016/ S0140-6736(17)30062-4

9. Goodship THJ, Cook HT, Fakhouri F, et al. Atypical hemolytic uremic syndrome and $\mathrm{C} 3$ glomerulopathy: conclusions from a "Kidney Disease: Improving Global Outcomes" (KDIGO) controversies conference. Kidney Int. 2017;91(3):539-551. doi:10.1016/j.kint.2016.10.005

10. Disorders NOfR. Atypical hemolytic uremic syndrome. 2019. Available from: https://rarediseases.org/rare-diseases/atypicalhemolytic-uremic-syndrome/. Accessed March 3, 2020.

11. Roumenina LT, Loirat C, Dragon-Durey M-A, Halbwachs-Mecarelli L, Sautes-Fridman C, Fremeaux-Bacchi V. Alternative complement pathway assessment in patients with atypical HUS. J Immunol Methods. 2011;365(1):8-26.

12. Noris M, Caprioli J, Bresin E, et al. Relative role of genetic complement abnormalities in sporadic and familial aHUS and their impact on clinical phenotype. Clin J Am Soc Nephrol. 2010;5(10):1844. doi: $10.2215 /$ CJN.02210310

13. Fremeaux-Bacchi V, Fakhouri F, Garnier A, et al. Genetics and outcome of atypical hemolytic uremic syndrome: a nationwide french series comparing children and adults. Clin J Am Soc Nephrol. 2013;8 (4):554-562. doi:10.2215/CJN.04760512

14. Kaplan BS, Ruebner RL, Spinale JM, Copelovitch L. Current treatment of atypical hemolytic uremic syndrome. Intractable Rare Dis Res. 2014;3(2):34-45. doi:10.5582/irdr.2014.01001

15. Schaefer F, Ardissino G, Ariceta G, et al. Clinical and genetic predictors of atypical hemolytic uremic syndrome phenotype and outcome. Kidney Int. 2018;94(2):408-418. doi:10.1016/j.kint.2018.02.029

16. Yoshida Y, Kato H, Nangaku M. Atypical hemolytic uremic syndrome. Ren Replace Ther. 2017;3(1):5. doi:10.1186/s41100-0160088-1
17. Al-Eisa A, Al-Hajeri M. Hemolytic uremic syndrome in Kuwaiti Arab children. Pediatr Nephrol. 2001;16(12):1093-1098. doi:10.1007/ s004670100036

18. Schifferli A, von Vigier RO, Fontana M, et al. Hemolytic-uremic syndrome in Switzerland: a nationwide surveillance 1997-2003. Eur J Pediatr. 2010;169(5):591-598. doi:10.1007/s00431-009-1079-9

19. Elliott EJ, Robins-Browne RM, Loughlin EV, et al. Nationwide study of haemolytic uraemic syndrome: clinical, microbiological, and epidemiological features. Arch Dis Child. 2001;85(2):125. doi:10.1136/ adc.85.2.125

20. Laurence J. Atypical Hemolytic Uremic Syndrome (aHUS): making the diagnosis. Clin Adv Hematol Oncol. 2012;10:10.

21. Quality assessment tool for observational cohort and cross-sectional studies. Study Quality Assessment Tools. 2019. Available from: https://www.nhlbi.nih.gov/health-topics/study-quality-assessmenttools. Accessed March 3, 2020.

22. Moher D, Liberati A, Tetzlaff J, Altman DG, The PG. Preferred Reporting Items for Systematic Reviews and Meta-Analyses: the PRISMA statement. PLoS Med. 2009;6(7):e1000097. doi:10.1371/ journal.pmed.1000097

23. Zimmerhackl LB, Besbas N, Jungraithmayr T, et al. Epidemiology, clinical presentation, and pathophysiology of atypical and recurrent hemolytic uremic syndrome. Semin Thromb Hemost. 2006;32 (2):113-120. doi:10.1055/s-2006-939767

24. Bayer G, Von Tokarski F, Thoreau B, et al. Etiology and outcomes of thrombotic microangiopathies. Clin J Am Soc Nephrol. 2019;14 (4):557-566. doi:10.2215/CJN.11470918

25. Ardissino G, Salardi S, Colombo E, et al. Epidemiology of haemolytic uremic syndrome in children. Data from the North Italian HUS network. Eur J Paediatr. 2016;175(4):465-473. doi:10.1007/s00431015-2642-1

26. Jenssen GR, Hovland E, Bjerre A, Bangstad HJ, Nygard K, Vold L. Incidence and etiology of hemolytic-uremic syndrome in children in Norway, 1999-2008 - a retrospective study of hospital records to assess the sensitivity of surveillance. BMC Infect Dis. 2014;14(1). doi:10.1186/1471-2334-14-265

27. Wuhl E, Van Stralen KJ, Wanner C, et al. Renal replacement therapy for rare diseases affecting the kidney: an analysis of the ERA-EDTA registry. Nephrol Dial Transpl. 2014,29(Supplement4):iv1-iv8. doi:10.1093/ndt/gfu030

28. Durkan AM, Kim S, Craig J, Elliott E. The long-term outcomes of atypical haemolytic uraemic syndrome: a national surveillance study. Arch Dis Child. 2016;101(4):387-391. doi:10.1136/archdischild2015-309471

29. Mallett A, Patel C, Salisbury A, Wang Z, Healy H, Hoy W. The prevalence and epidemiology of genetic renal disease amongst adults with chronic kidney disease in Australia. Orphanet $J$ Rare Dis. 2014;9(1):98. doi:10.1186/1750-1172-9-98

30. Hooman N, Sadeghian M, Jahangiri F, Hosseini S. The prevalence and incidence of atypical hemolytic uremic syndrome in Iran: a systematic review and Meta-Analysis Protocol Study. J Compr Ped. 2018;9(1):e56080.

31. Chang H-GH, Tserenpuntsag B, Kacica M, Smith PF, Morse DL. Hemolytic uremic syndrome incidence in New York. Emerg Infect Dis. 2004;10(5):928-931. doi:10.3201/eid1005.030456

32. Proulx F, Sockett P. Prospective surveillance of Canadian children with the haemolytic uraemic syndrome. Pediatr Nephrol. 2005;20 (6):786-790. doi:10.1007/s00467-005-1843-7

33. Terrell DR, Williams LA, Vesely SK, Lämmle B, Hovinga JAK, George JN. The incidence of thrombotic thrombocytopenic purpura-hemolytic uremic syndrome: all patients, idiopathic patients, and patients with severe ADAMTS-13 deficiency. $J$ Thromb Haemost. 2005;3(7):1432-1436. doi:10.1111/jth.2005.3.issue-7

34. Constantinescu AR, Bitzan M, Weiss LS, et al. Non-enteropathic hemolytic uremic syndrome: causes and short-term course. Am J Kidney Dis. 2004;43(6):976-982. doi:10.1053/j.ajkd.2004.02.010 
35. Berger BE. Atypical hemolytic uremic syndrome: a syndrome in need of clarity. Clin Kidney J. 2018;12(3):338-347. doi:10.1093/ckj/ sfy066
36. Copelovitch L, Kaplan BS. Streptococcus pneumoniae-associated hemolytic uremic syndrome: classification and the emergence of serotype 19A. Pediatrics. 2010;125(1):e174. doi:10.1542/peds.2007-2017

\section{Publish your work in this journal}

Clinical Epidemiology is an international, peer-reviewed, open access, online journal focusing on disease and drug epidemiology, identification of risk factors and screening procedures to develop optimal preventative initiatives and programs. Specific topics include: diagnosis, prognosis, treatment, screening, prevention, risk factor modification,

Submit your manuscript here: https://www.dovepress.com/clinical-epidemiology-journal systematic reviews, risk \& safety of medical interventions, epidemiology \& biostatistical methods, and evaluation of guidelines, translational medicine, health policies \& economic evaluations. The manuscript management system is completely online and includes a very quick and fair peer-review system, which is all easy to use. 